University of Nebraska - Lincoln

DigitalCommons@University of Nebraska - Lincoln

8-15-2013

\title{
UNUSUAL WINTERING DISTRIBUTION AND MIGRATORY BEHAVIOR OF THE WHOOPING CRANE (GRUS AMERICANA) IN 2011-2012
}

Greg D. Wright

Mary J. Harner

James D. Chambers

Follow this and additional works at: https://digitalcommons.unl.edu/usarmyceomaha

This Article is brought to you for free and open access by the U.S. Department of Defense at

DigitalCommons@University of Nebraska - Lincoln. It has been accepted for inclusion in US Army Corps of Engineers by an authorized administrator of DigitalCommons@University of Nebraska - Lincoln. 


\title{
UNUSUAL WINTERING DISTRIBUTION AND MIGRATORY BEHAVIOR OF THE WHOOPING CRANE (GRUS AMERICANA) IN 2011-2012
}

\author{
GREG D. WRIGHT, ${ }^{1,3}$ MARY J. HARNER, ${ }^{1}$ AND JAMES D. CHAMBERS ${ }^{2}$
}

\begin{abstract}
The last, self-sustaining population of Whooping Cranes (Grus americana), the Aransas-Wood Buffalo population, has overwintered almost exclusively along the Gulf Coast of Texas, USA, in and around the Aransas National Wildlife Refuge during recent decades. In late autumn and winter 2011-2012, Whooping Cranes were observed several hundred kilometers from coastal wintering grounds, with at least 13 Whooping Cranes in central Texas, south-central Kansas, and central Nebraska from November 2011 to early March 2012. Notably, family groups of Whooping Cranes were observed around a Texas reservoir, Granger Lake, over a 3-month period. An extreme drought, coupled with record warm temperatures in the southern and central United States, may have interacted to influence behaviors and distributions of Whooping Cranes during winter 2011-2012. Such observations suggest that Whooping Cranes may be more opportunistic in use of wintering habitat and/or more likely to re-colonize inland historical sites than previously thought. Continued documentation of Whooping Cranes overwintering in areas other than the Texas coast and/or altering timing of migration will be important for protection and management of additional winter habitat as well as for informing population estimates for the Aransas-Wood Buffalo Population of Whooping Cranes. Received 6 May 2013. Accepted 15 August 2013.
\end{abstract}

Key words: Aransas National Wildlife Refuge, Cheyenne Bottoms State Waterfowl Management Area, Kansas, Granger Lake, Texas, Platte River, Nebraska, Quivira National Wildlife Refuge, Kansas, wintering habitat.

The Whooping Crane (Grus americana) is one of the most endangered species of birds in North America and the world (National Audubon Society 2006, IUCN 2012). The last wild, selfsustaining population of Whooping Cranes, the Aransas-Wood Buffalo population (AWBP), migrates more than $3,800 \mathrm{~km}$ from Wood Buffalo National Park, Canada, to in and around Aransas National Wildlife Refuge (NWR), Texas, USA, and has rebounded from fewer than 20 individuals in the early 1940s (Allen 1952) to over 250 individuals in 2011-2012 (Strobel et al. 2012). This population expansion represents tremendous improvement, but the species remains far from meeting recovery goals, which include the AWBP numbering above 1,000 individuals if two additional wild, self-sustaining flocks of Whooping Cranes cannot be established (CWS and USFWS 2007). A key factor in the recovery of Whooping Cranes is provision of adequate habitat across the species' range, including wintering grounds.

Historically, Whooping Cranes wintered in prairies, marshes, and coastal lagoons throughout southwestern Louisiana, the Gulf Coast of Texas, the Rio Grande Delta in northeastern Mexico, as well as inland grasslands, including the tablelands of west-central Texas and the high plateaus of

\footnotetext{
${ }^{1}$ The Crane Trust, 6611 W. Whooping Crane Drive, Wood River, NE, 68883, USA.

${ }^{2}$ United States Army Corps of Engineers, 3100 Granger Dam Road, Granger, TX, 76530, USA.

${ }^{3}$ Corresponding author; e-mail: gwright@cranetrust.org
}

central Mexico (Stevenson and Griffith 1946, Allen 1952, CWS and USFWS 2007). Overharvesting of Whooping Cranes and habitat loss and degradation led to precipitous declines in Whooping Cranes by the end of the 19th century (McIlhenny 1943, Allen 1952). By the time Aransas NWR was created in 1937, its lands encompassed nearly all of the wintering range of the remaining migratory Whooping Cranes (Stevenson and Griffith 1946, Allen 1952). As the AWBP increased over subsequent decades, locations of winter territories expanded to surrounding marshlands, and territory sizes decreased, permitting more birds to occupy coastal areas in and around Aransas NWR, including nearby Matagorda Island (Stehn and Johnson 1987), an area that Whooping Cranes used prior to their decline (Allen 1952). Occasionally juvenile Whooping Cranes have been observed elsewhere during winter, such as a juvenile in Oklahoma and Kansas in 1987 (Stehn 1992), a juvenile in Oklahoma and Nebraska in 2008-2009 (Stehn 2009), and a juvenile near Medford, Oklahoma, in 2009 (Stehn 2010). However, most Whooping Cranes have remained concentrated within the brackish marshes of the Gulf Coast during recent winters.

Such a small, isolated population within a limited geographic area is vulnerable to stochastic events (Mills 2007), such as chemical spills along the Gulf Intracoastal Waterway and hurricanes that could decimate the population (CWS and 
USFWS 2007). Changing climatic and environmental conditions may further negatively influence availability of fresh water and associated food resources for Whooping Cranes (CWS and USFWS 2007, Chavez-Ramirez and Wehtje 2012). Collectively, such factors threaten the long-term viability of the species, and the future of Whooping Cranes may depend, in part, on dispersal of the core population from current wintering grounds to other suitable areas within its historical winter range.

During winter 2011-2012, family groups of Whooping Cranes were observed away from the Texas Gulf Coast for the first time in recent history. Birds were far beyond the sampling frames for the U.S. Fish and Wildlife Service Wintering Whooping Crane Abundance Survey (Strobel et al. 2012). Observers did, however, record locations and behaviors of Whooping Cranes in these unusual areas in a variety of formats, including internal agency notes and electronic discussion lists. Herein we summarize winter 2011-2012 sightings and discuss implications of this expanding winter distribution of Whooping Cranes.

\section{METHODS}

We contacted personnel from the U.S. Army Corps of Engineers, U.S. Fish and Wildlife Service, and Kansas Department of Parks and Wildlife, as well as searched LISTSERV sites (KSBIRD-L 2012, Texbirds LISTSERV 2012) for summaries of reported sightings of Whooping Cranes in atypical wintering areas from November 2011 to March 2012. Site-specific information was compiled and evaluated to eliminate redundant data points, and when possible, more than one source was contacted to ensure validity of observations. We conservatively summarized observations. In several cases birds likely were present for longer periods, but we present only sightings reported with daily records of location. We included descriptions of habitats occupied when such details were available through photographic documentation or reported by observers.

\section{RESULTS}

Whooping Cranes were observed hundreds of kilometers away from typical wintering grounds during winter 2011-2012 (Fig. 1), with birds at Granger Lake, a reservoir in central Texas (Williamson County); at Quivira National Wildlife Refuge in south-central Kansas (Stafford
County); near Cheyenne Bottoms State Waterfowl Management Area in central Kansas (Ellsworth County); and along the Platte River in central Nebraska (Dawson County).

Whooping Cranes were most commonly reported from Granger Lake, with sightings spanning mid-November 2011 through early March 2012, and as many as nine birds seen on some occasions (Fig. 2; Texbirds LISTSERV 2012; JDC, unpubl. data). The first sighting at Granger Lake was on 14 November, when observers saw four Whooping Cranes in flight from the dam. The next report came on 21 November when a flock of three birds, composed of two adults and one juvenile, was feeding in a cornfield near the lake. One week later, two adults and one juvenile were in an agricultural field near the lake, and a single family group of the same composition was observed three more times 3-6 December. On 7 December two family groups were reported, both containing two adults and one juvenile. From 7 December 2011 until 2 February 2012, Whooping Cranes were seen regularly, and multiple observers documented three and six individuals during this time. Then, on 7 February 2012, an observer saw nine Whooping Cranes congregated in an area immediately north of Granger Lake, where six birds previously had been observed. Nine individuals were seen multiple times at or near Granger Lake until 19 February 2012, and six individuals were reported on 3 March 2012. Personal observations (JDC, pers. obs.) and photographs revealed that Whooping Cranes were associated with agricultural fields, grazed pastures, depressional wetlands, and dammed ponds around Granger Lake.

Up to six Whooping Cranes were reported on some occasions at Quivira NWR from 19 November 2011 to 24 January 2012 in marsh habitats (Fig. 2; KSBIRD-L 2012; B. A. Jones, pers. comm.). On 19 November, a single Whooping Crane was observed with a large group of Sandhill Cranes (G. canadensis) near Quivira NWR, and a single Whooping Crane was reported daily through 27 November. A single Whooping Crane again was reported on 5 December, and an individual was reported daily until 19 December in the same area. Additional sightings at Quivira NWR included four Whooping Cranes on 24-25 November, three on 7 December, and six on 24 January 2012 (Fig. 2).

Three Whooping Cranes, two adults and one juvenile, were reported from private land near 


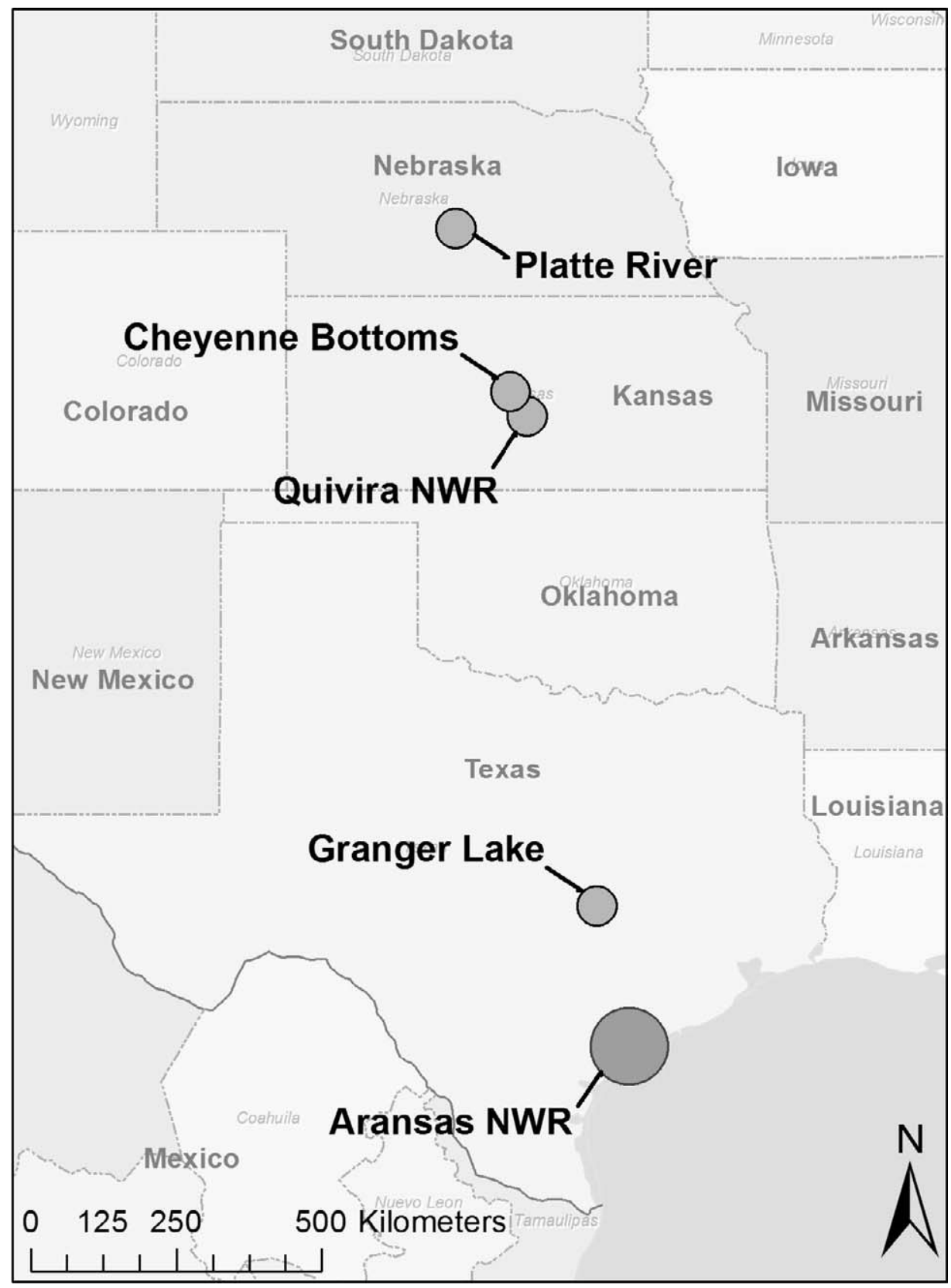

FIG. 1. Locations of reported Whooping Cranes mid-November 2011 through mid-February 2012. Large circle denotes their primary wintering area along the Texas Gulf Coast in and around the Aransas National Wildlife Refuge (NWR), and small circles indicate additional sites occupied by Whooping Cranes during winter of 2011-2012.

Cheyenne Bottoms State Wildlife Area from late November 2011 to mid-January 2012 (Fig. 2). A family group was seen from 23 November to 13 December 2011 (K. E. Grover, pers. comm.). Additional information obtained from a listserv accounted for three birds multiple times from 14 December to 24 January 2012 (KSBIRD-L 2012). The birds likely were present between reported observations, as the sightings are from the same location and of the same flock composition, but 


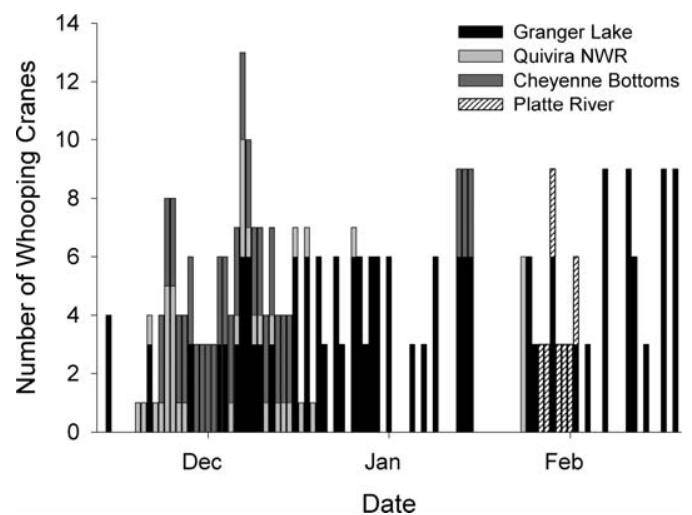

FIG. 2. Number of confirmed sightings of Whooping Cranes outside of the Texas Gulf Coast mid-November 2011 through mid-February 2012. Additional sightings were reported through early March 2012, but these later observations were excluded from the figure, because they may have been birds initiating early migration.

only specific dates recorded are depicted in figure 2.

On 27 January 2012, three Whooping Cranes, two adults and one juvenile, were confirmed within the main channel of the Platte River near Jeffery Island in Overton, Nebraska (M. C. Tacha, pers. comm.). The Whooping Cranes last were seen on the Platte River on 2 February 2012. On 4 February 2012, heavy snow and strong north winds impacted the area; the birds were not resighted after the storm.

\section{DISCUSSION}

It is difficult to disentangle whether Whooping Cranes were overwintering, extending migration, or exhibiting some combination of these behaviors during winter 2011-2012, but it is clear that large numbers of Whooping Cranes, notably family groups, were away from Aransas NWR during the typical overwintering period. The winter of 2011-2012 was the fourth warmest on record for the United States (NOAA 2012), and Texas experienced exceptional drought during the months when Whooping Cranes typically overwinter along the Gulf Coast (U.S. Drought Monitor 2012). In addition to the unusual distribution of Whooping Cranes, Sandhill Cranes were far north of typical wintering grounds, with several thousand along the Platte River in central Nebraska during winter 2011-2012 (MJH, unpubl. data), providing further evidence that mild conditions in the central United States were favorable for cranes during winter months.

A number of interacting factors likely contributed to the unusual distribution of Whooping Cranes in 2011-2012. During autumn 2011 migration, Whooping Cranes may have lingered at stopover sites because of warmer conditions and availability of open, unfrozen water, either delaying arrival at Aransas NWR or terminating migration at more northerly sites. Alternatively, Whooping Cranes may have reached Aransas NWR and subsequently departed, possibly because of poor habitat conditions associated with the drought or overcrowding linked to an expanding population. Some cranes might have traveled between sites and/or initiated extremely early migration, such as the Whooping Cranes along the Platte River in late January. Historically, few Whooping Cranes have been documented migrating before late March, except in 2010 when individuals were observed in Oklahoma in late February and early March (Stehn 2010). Offrefuge sightings of Whooping Cranes in 2012 were considerably earlier than previous records, suggesting that some individuals were overwintering rather than migrating-especially the Granger Lake birds.

Three of the non-coastal sites occupied by Whooping Cranes during winter 2011-2012 were within or adjacent to areas designated as critical habitat for migrating Whooping Cranes (Platte River, Cheyenne Bottoms, Quivira NWR; USFWS 1978). Granger Lake is not an area identified as critical habitat, but it lies within the migratory corridor and likely serves as a shortduration stopover site. The region surrounding Granger Lake is moderately developed, populated, and bisected by multiple roads (JDC, pers. obs.). Because of these factors and publicity generated by these Whooping Cranes in 20112012, it is unlikely that more have wintered around Granger Lake in recent times. Whooping Cranes did, however, inhabit this inland region during the mid-19th century, with records of "immense flocks" of Whooping Cranes in Williamson County during spring 1884 and Whooping Cranes as a "favorite game fowl" and "an abundant winter resident" in nearby McLennan County (Stevenson and Griffith 1946 and references therein). Therefore, the individuals at Granger Lake might have been re-occupying an historical-use area, even though the natural habitat has been altered from a riverine landscape to its 
current condition as a flood-control reservoir. Alternatively, the current habitat conditions of the drawn-down reservoir may have attracted the birds during migration.

The condition of Granger Lake and surrounding lands provided resources conducive to multiplemonth occupancy by Whooping Cranes in winter 2011-2012. Granger Lake is a reservoir on the San Gabriel River in Texas owned and managed by the U.S. Army Corps of Engineers for flood control, water supply, and recreation. The reservoir was impounded in 1980 and has experienced extreme siltation over the last three decades. Under normal conditions, the lake covers approximately 1,800 ha and has a relatively shallow depth averaging $3 \mathrm{~m}$, with inter-annual waterlevel fluctuations $<1 \mathrm{~m}$ (JDC, unpubl. data). The lake reached an all-time low on 9 November 2011, exposing many sand bars and mud flats, as well as numerous crayfish and bivalves (JDC, pers. obs.). This decline in lake level coincided with the autumn migration of Whooping Cranes through Texas, and birds frequently were observed foraging around the reservoir margin until lake levels rose $>1 \mathrm{~m}$ by late February 2012, once again submerging mud flats. The great (at least nine birds) and extended use (three months) suggest that the reservoir and surrounding lands provided suitable conditions during a drought for Whooping Cranes to acquire resources necessary for survival during winter. These observations warrant further investigation to understand how fluctuating water levels of reservoirs influence use by Whooping Cranes throughout the entire migratory corridor, as well as whether there are any negative effects of exposed sediments on the birds, such as detected for Sandhill Cranes along a depleted reservoir in New Mexico, USA (DeRagon et al. 2005).

Collectively, these unusual distributional patterns suggest that Whooping Cranes may be much more flexible in selection of wintering habitat than previously described, and this plasticity might be essential to the growth of the population outside of Aransas NWR as demand for wintering habitat increases. It is likely that other areas exist in Texas and surrounding states that could provide adequate resources to wintering Whooping Cranes, if birds have a way to gain knowledge of those sites. The successful reintroduction of Whooping Cranes in the eastern United States (CWS and USFWS 2007), as well as their historical distribution (e.g., Allen 1952), illustrates the species' potential to occupy diverse habitats during winter. However, the current paradigm of wintering habitat conservation for AWBP focuses on the preservation and creation of favorable coastal habitats immediately adjacent to areas already occupied by Whooping Cranes in and around Aransas NWR (CWS and USFWS 2007). Documentation of overwintering site use and behavior-especially far from the Gulf Coastwill inform population estimates for AransasWood Buffalo Whooping Cranes and help guide protection and management of wintering habitat over a larger area. Such documentation also may allow us to monitor interactions between wild and reintroduced Whooping Cranes should their habitats eventually overlap. To facilitate this, ongoing efforts will be needed to increase public awareness about reporting observations of Whooping Cranes, as well as to systematically document and validate off-refuge sightings during winter.

\section{ACKNOWLEDGMENTS}

We thank two anonymous reviewers, A. T. Pearse, K. Geluso, and J. D. Oates for comments on earlier versions of this manuscript. We thank regional biologists, land managers, and the public for reporting sightings of Whooping Cranes. The Crane Trust provided funding for this research.

\section{LITERATURE CITED}

Allen, R. P. 1952. The Whooping Crane. Research Report Number 3. National Audubon Society, New York, USA.

Canadian Wildlife SeRvice (CWS) AND U.S. Fish AND WildLIFE SERVICE (USFWS). 2007. International recovery plan for the Whooping Crane. Recovery of Nationally Endangered Wildlife (RENEW), Ottawa, Ontario, Canada; and U.S. Fish and Wildlife Service, Albuquerque, New Mexico, USA.

Chavez-Ramirez, F. and W. Wehtue. 2012. Potential impact of climate change scenarios on Whooping Crane life history. Wetlands 32:11-20.

Deragon, W., W. Brown, G. Garber, and M. Richard. 2005. Sandhill Crane mortality during fall migration stopover in north-central New Mexico, Fall 2001. Proceedings North American Crane Workshop 9:3-5.

INTERNATIONAL UNION FOR CONSERVATION OF NATURE (IUCN). 2012. IUCN Red List of Threatened Species. Version 2012.2. www.iucnredlist.org (accessed 31 Jan 2013).

KSBIRDS-L. 2012. Birds and their habitats in Kansas. Kansas State University, Manhattan, USA. listserv. ksu.edu/archives/ksbird-1.html (accessed 15 Mar 2012).

MCIlHEnNy, E. A. 1943. Major changes in the bird life of southern Louisiana during sixty years. Auk 60:541549. 
MILLS, L. S. 2007. Conservation of wildlife populations: demography, genetics, and management. Blackwell Publishing, Malden, Massachusetts, USA.

NAtional Audubon Society. 2006. America's top ten most endangered birds. National Audubon Society, Public Policy Office, Washington, D.C., USA. web4. audubon.org/news/top10/Top10_Endangered_Species. pdf (accessed 31 Jan 2013).

NATIONAL OCEANIC AND ATMOSPHERIC ADMINISTRATION (NOAA). 2012. Winter 2011-2012 recap [video]. NOAA, National Climatic Data Center, Asheville, North Carolina, USA. www.climate.gov/news-features/ videos/winter-2011-2012-recap (accessed 31 Jan 2013).

STEHN, T. V. 1992. Unusual movements and behaviors of color-banded Whooping Cranes during winter. Proceedings North American Crane Workshop 6:95101.

Stehn, T. 2009. Whooping Crane recovery activities October, 2008-October, 2009. U.S. Fish and Wildlife Service, National Wildlife Refuge System, Aransas National Wildlife Refuge, Austwell, Texas, USA.

Stehn, T. 2010. Whooping Crane recovery activities: October, 2009-September, 2010. U.S. Fish and
Wildlife Service, Aransas National Wildlife Refuge, Austwell, Texas, USA.

Stehn, T. V. and E. F. JohnSON. 1987. Distribution of winter territories of the Whooping Crane on the Texas coast. Pages 180-195 in Proceedings 1985 Crane Workshop (J. C. Lewis, Editor). Platte River Whooping Crane Habitat Maintenance Trust and U.S. Fish and Wildlife Service, Grand Island, Nebraska, USA.

Stevenson, J. O. and R. E. GRIFFITH. 1946. Winter life of the Whooping Crane. Condor 48:160-178.

Strobel, B., M. J. Butler, and G. Harris. 2012. AransasWood Buffalo Whooping Crane Abundance Survey (2011-2012). U.S. Fish and Wildlife Service, National Wildlife Refuge System, Austwell, Texas, USA.

TEXBIRDS LISTSERV. 2012. Birding discussion list for Texas. lists.texbirds.org/texbirds.html (accessed 15 Mar 2012).

U.S. Drought Monitor. 2012. U.S. drought monitor archives. University of Nebraska, National Drought Mitigation Center, Lincoln, USA. droughtmonitor.unl. edu/archive.html (accessed 31 Jan 2013).

U.S. FISH AND WILDLIFE SERVICE (USFWS). 1978. Determination of critical habitat for the Whooping Crane. Federal Register 43:20938-20942. 